\title{
Benign tremulous Parkinsonism: a unique entity or another facet of Parkinson's disease?
}

\author{
Wissam Deeb, Wei Hu, Leonardo Almeida, Addie Patterson, Daniel Martinez-Ramirez ${ }^{*}$ and Aparna Wagle Shukla*
}

\begin{abstract}
Benign tremulous parkinsonism (BTP) is characterized by a prominent tremor that occurs both at rest and with action in conjunction with other mild features of parkinsonism. The progression of symptoms is typically slow and there is often a positive family history. Although BTP is included within the phenotypic spectrum of Parkinsonism its exact relationship with idiopathic Parkinson's disease remains unclear. Treatment of BTP is challenging especially considering the poor response to levodopa, therefore surgical therapies such as deep brain stimulation surgery are sought for treatment of these tremors. In this review, we will summarize the clinical features, diagnosis,

neuropathology and treatment for BTP.
\end{abstract}

\section{Background}

Tremor is a common symptom seen in movement disorders clinical practice $[1,19]$. The most common cause of tremors is essential tremor and the other important differential is idiopathic Parkinson's disease (PD) [2-5]. The basic difference between the arm tremors seen in these two conditions is that essential tremor is characterized by postural and action tremor whereas PD tremor is mostly a resting tremor [11]. Benign tremulous parkinsonism was first characterized extensively in cohort of 16 patients followed at Mayo Clinic who shared similar phenotype and exhibited a unique clinical course. These patients had a pronounced asymmetric resting tremor in conjunction with mild to moderate postural and action tremor and mild parkinsonian signs. The tremors did not respond to alcohol. Although this constellation of features was tempting to be categorized as PD, the clinicians at Mayo Clinic observed unique differences. The progression of symptoms was notably slow, there was a significant family history and unlike typical PD, there were fewer nonmotor features. Prior to this report, there were only few cases briefly mentioned in the literature. The authors referred to this condition as benign

\footnotetext{
* Correspondence: Daniel.Martinez-Ramirez@neurology.ufl.edu; aparna. shukla@neurology.ufl.edu

Wissam Deeb and Wei Hu are first co-authors.

Department of Neurology, University of Florida Health - College of Medicine, Center for Movement Disorders and Neurorestoration, Gainesville, FL, USA
}

tremulous Parkinsonism (BTP). Since then a debate has surfaced whether BTP represents a unique disorder or the clinicians are facing a variant within the spectrum of tremor-predominant idiopathic PD [10, 42].

According to the Mayo Clinic series [21] which was also later reinforced by other groups [26, 41], BTP is characterized by rest and action tremor at onset that remains persistent as the dominant feature for at least 8 years with only a minimal progression of other parkinsonism signs. The gait disorder essentially comprises of mild stooping or a reduced arm swing instead of classic shuffling gait with progressive deterioration of balance. These patients display a poor and unpredictable response to levodopa therapy. Most of them present at a relatively younger age of onset in the fifth decade and have a family history which suggests a strong underlying genetic etiology. The prognosis is much better compared to idiopathic PD. Postmortem findings indicate fewer pathological changes in the substantia nigra further consolidating the concept that BTP is a distinct entity [41]. Some argue BTP represents one end of the clinical spectrum of PD which is tremor-predominant PD [10]. This subtype typically progresses the slowest amongst the various PD subtypes and the presence of significant motor findings in the beginning may be minimal. In an editorial on study by Selikhova et al., it was recommended that patients with rest and action tremors and 
minimal Parkinsonism features should be categorized as "monosymptomatic tremor at rest". Since only some of the patients initially diagnosed as BTP eventually displayed typical pathological features of PD, it was felt that BTP was a misnomer [10] (Table 1).

Whether BTP should truly be considered "benign" is controversial. The term "benign" was proposed due to a slower rate of progression of other Parkinsonism symptoms which could indicate a better prognosis than idiopathic PD. However, there is a suggestion that these patients may also have sudden worsening of other Parkinsonian signs, such as rigidity and gait resulting in significant motor disability [39]. Another example of "benign" movement disorder, is essential tremor which was labeled as "benign" for decades in literature until the most recent years, when gait dysfunction and memory problems in ET became wellknown. Considering these additional features, some experts recommend avoiding the term "benign" when describing ET. Similarly, clinicians must also be cautious regarding the usage of the term "benign" in the context of BTP until further longitudinal studies can better establish or refute such an assumption. Followup studies should focus on the rate of progression, and the co-occurrence of non-motor symptoms.

\section{Pathological findings in BTP}

There is scant knowledge on the neuropathology of BTP. In one study, Selikhova M. et al. compared brain pathology specimens of 15 BTP cases with age and disease duration-matched PD controls. They found that most BTP patients had lesser neuronal loss in the ventrolateral portion of the substantia nigra than their PD controls. Similar to PD, BTP cases had Lewy bodies in the substantia nigra and other brainstem structures. These findings suggest there is a slower nigral cell degeneration which correlates with relatively stable Parkinsonism observed throughout the clinical course of BTP. It is noteworthy that tremor predominant subtype of PD also has lesser neuronal loss in locus coeruleus (LC) and in medial and lateral parts of substantia nigra [20]. Therefore, it will be worthwhile to conduct a pathology study that could identify the key differences between BTP and tremor predominant PD.

\section{Genetic aspects}

A striking finding to note with BTP is the positive family history of tremor identified in nearly 31 to $63 \%$ of patients $[21,41]$, in contrast to only 7 to $16 \%$ of idiopathic PD patients [12, 32, 34, 35, 38]. These findings are in contrast to a lower prevalence of family history in idiopathic PD (<10\%) and highlight an underlying genetic etiology to play a substantial role.

The genetic underpinnings of BTP albeit intriguing, only few cases have shown positive gene tests. LRRK2 mutation is responsible for about $1 \%$ of sporadic PD patients and $4 \%$ of hereditary PD cases. Clarimon J. et al. in a series of patients who had clinical characteristics similar to BTP, found new LRRK2 (V2390M) mutation. Although authors allude to clinical similarities between their patients and the BTP case series from Mayo, the authors refer to the patients as tremor dominant parkinsonism [9]. Rizzo et al. [37] described another patient with Dardarin mutation who had clinical presentation consistent with BTP. In addition, compound heterozygous parkin gene mutation was identified in one patient [41]. Both LRRK2 mutations and parkin gene have been linked to various heterogeneous phenotypes in idiopathic PD $[7,16]$. Considering the presence of significant family history, further studies are required to identify the underlying genetic aspect of BTP $[29,30]$.

\section{Clinical features}

As reported in multiple case series [21, 26, 41], the presenting symptom in BTP is a moderate asymmetric upper limb tremor [21], with majority presenting with a combination of rest and postural/action tremors [41]. These tremors tend to only slowly worsen over time, and typically do not respond to alcohol [21]. In the early course of BTP, only mild features of Parkinsonism such as bradykinesia, rigidity, stooped posture and a reduced arm swing were observed [21, 41]. Interestingly, these Parkinsonian signs remain relatively unchanged for many years. Only few patients develop mild non-motor symptoms including dysautonomia, constipation, erectile

Table 1 Clinical Characteristics of patients with Benign Tremulous Parkinsonism

\begin{tabular}{|c|c|c|c|c|c|c|}
\hline Study & $\begin{array}{l}\operatorname{Sex} \\
(M / F)\end{array}$ & $\begin{array}{l}\text { Mean Age of onset } \\
\text { (range) }\end{array}$ & Initial symptoms & $\begin{array}{l}\text { Disease duration } \\
\text { (years, range) }\end{array}$ & Treatment response & $\begin{array}{l}\text { Family } \\
\text { history }\end{array}$ \\
\hline $\begin{array}{l}\text { Josephs et } \\
\text { al. }\end{array}$ & $10 / 6$ & $58.5(42-71)$ & Unilateral hand rest tremor (13/16) & $11.1(8-25)$ & $\begin{array}{l}\text { No benefit by LDa } \\
(\geq 600 \mathrm{mg} / \mathrm{d})\end{array}$ & $10 / 16$ \\
\hline $\begin{array}{l}\text { Selikhova et } \\
\text { al. }\end{array}$ & $9 / 7$ & $59(30-72)$ & $\begin{array}{l}\text { Unilateral hand rest tremor }(11 / 16) \text {, } \\
\text { rest and postural/action tremor }(5 / 16)\end{array}$ & $24(12-50)$ & $\begin{array}{l}\text { Not responsive to LD }(9 / 15) \text {, } \\
\text { though } 6 / 15 \text { had early benefit }\end{array}$ & $5 / 15$ \\
\hline $\begin{array}{l}\text { Leventoglu } \\
\text { et al. }\end{array}$ & $16 / 7$ & $66.6(50-89)$ & Unilateral hand rest tremor $(18 / 23)$ & 5 & $\begin{array}{l}\text { Little improvement to LD } \\
(11 / 18)\end{array}$ & $4 / 23$ \\
\hline
\end{tabular}

${ }^{\mathrm{a}} L D$ Levodopa 
dysfunction, and bladder dysfunction [21]. There is a male predominance and the age of onset is relatively younger ranging from 58.5 to 66.6 years $[21,26,41]$.

\section{Diagnosis}

It is important to differentiate BTP from other similar tremor syndromes [36], including the commonly seen tremor-predominant PD and essential tremor. Each alternative tremor syndromes has specific features which should be given due consideration when making the diagnosis.

1) Mono-symptomatic resting tremor, identified as a pure or predominant rest tremor: These patients however do not have other Parkinsonism symptoms and signs [11].

2) Essential tremor: BTP tremors are postural +/kinetic and there is a strong family history. However unlike the tremor of BTP, use of alcohol attenuates tremors and there are no accompanying features of parkinsonism [22].

3) Isolated tremor and subtle Parkinsonian signs relevant to aging [25]: The parkinsonian features manifest at an older age which is different from BTP in which the mean age of onset is usually less than 60 years.

5) PD initially manifesting as essential tremor: These patients $[6,15]$, are characterized by a postural tremor or head tremor who develop parkinsonian symptoms later in life. Their clinical features and disease course are consistent with typical idiopathic PD.

6) Combined essential tremor with PD [24]: In this syndrome the rate of progression for PD follows the typical course unlike patients with BTP.

7) "Tremor-predominant PD": This term encompasses a specific phenotype of PD to distinguish patients who have prominent tremors as the main clinical presentation from those who have akinetic-rigid type or those who can be categorized into postural instability-gait disturbance phenotype. The term has a broader connotation and does not necessarily imply presence of other key features of BTP including remarkable family history, and a slow course of progression.

BTP is relatively new, therefore lacks clinical validity and specific diagnostic criteria. In the early stages, it maybe difficult to clinically differentiate BTP from typical idiopathic $\mathrm{PD}$. If there is dopamine depletion in the brain, the patient is likely to suffer from PD [28]. The clinicians should consider BTP if the patients present with prominent rest tremor in conjunction with postural and action tremors. BTP becomes very likely if tremor remains the major sign/ symptom with mild and stable Parkinsonism despite several years of follow-up. The other clinical clues include the absence of a satisfactory response to levodopa therapy and a positive family history. A Dopamine transporter Singlephoton emission computed tomography (DAT SPECT) test which is sensitive and specific for diagnosis of degeneration related parkinsonism has not been reported in BTP, may be helpful for diagnosis. If BTP is distinct from tremor predominant PD, DAT SPECT is expected to be normal [36].

\section{Treatment}

BTP patients have usually shown refractoriness to levodopa therapy, particularly in the early disease stages, despite reaching average doses of $900 \mathrm{mg} /$ day [21, 40]. Selikhova et al. [41] found that in a series of 12 patients, six patients had a transient early response to high doses of levodopa (400-1250 mg/day), and over half of the patients did not have a satisfactory response to dopaminergic therapy [41]. Interestingly, substantial levodopa complications including dyskinesias have not been described in these patients. The effect of medications other than levodopa, particularly the neuroprotective agents $[8,31]$ and anti-tremor medications, on the course and tremor symptoms in these patients require further studies.

Over the past decade, a large body of evidence has established the application of deep brain stimulation (DBS) surgery in the management of medication refractory tremors for PD [13, 14, 18, 23, 27] and essential tremor [17, 33]. A review of 15 BTP patients who received DBS showed significant improvement of symptoms [40]. Of these, 12 patients received ventral intermediate (VIM) nucleus of the thalamus (8 patients with unilateral and 4 with bilateral leads). The remaining three patients received bilateral subthalamic nucleus (STN) stimulation. All of these patients received a mean levodopa challenge dose of $900 \mathrm{mg} / \mathrm{d}$ (300 mg 3 times daily), with about half of them showing an initial but suboptimal response, whereas the other half had no benefit with levodopa use. Overall there was a satisfactory response to either VIM or STN stimulation, with seven patients being tremor-free and six patients remaining with minimal residual tremor at their last follow-up visit. Upon reviewing these impressive benefits, it appears BTP patients would be suitable for DBS at earlier stages of disease. VIM could be an appropriate target as tremors are the predominant feature and other Parkinsonian signs are mild. The current available data, is not adequate to establish practice parameters for DBS which could be accomplished through future well-powered studies.

\section{Conclusion}

BTP is clinically characterized by asymmetric tremors at onset, tremors present at rest, postural and action tremors and they remain as the prominent clinical feature for many years. These tremors donot respond to alcohol. Tremors are accompanied by other mild features 
of parkinsonism which do not progress at typical rates. Unlike typical PD, there family history is significant and the nonmotor features are not that frequent. Autopsy studies have found fewer pathological changes in the substantia nigra. Whether BTP is a distinct clinical entity or is a subtype of PD is currently debatable. Treatment of BTP is challenging, response to levodopa is poor even when tried at high doses. Athough small scale studies have shown bilateral DBS of VIM and STN to exhibit excellent outcomes, prospective studies with larger sample sizes, and randomized target selection, are required to determine the long-term efficacy and durability [40].

\section{Acknowledgements}

We acknowledge all the authors of publications regarding the topics of Benign Tremulous Parkinsonism.

\section{Authors' contributions}

WD, WH, LA, AP, DMR and AWS participated in the design of the study; WD, WH and AWS prepared the manuscript. LA, AP, DMR and AWS revised the manuscript. All authors read and approved the final manuscript.

\section{Competing interests}

The authors declare that they have no competing interests.

Received: 13 March 2016 Accepted: 10 May 2016

Published online: 20 May 2016

\section{References}

1. Ahlskog, J.E. Parkinson's Disease Treatment Guide for Physicians. New York, USA: Oxford University Press; 2009.

2. Barbe MT, Liebhart L, Runge M, Pauls KA, Wojtecki L, Schnitzler A, Allert N, Fink GR, Sturm V, Maarouf M, Timmermann L. Deep brain stimulation in the nucleus ventralis intermedius in patients with essential tremor: habituation of tremor suppression. J Neurol. 2011;258:434-9.

3. Benabid AL, Pollak P, Gervason C, Hoffmann D, Gao DM, Hommel M, Perret $\mathrm{JE}$, de Rougemont J. Long-term suppression of tremor by chronic stimulation of the ventral intermediate thalamic nucleus. Lancet. 1991;337: 403-6.

4. Braak H, Bohl JR, Muller CM, Rub U, de Vos RA, Del Tredici K. Stanley Fahn Lecture 2005: the staging procedure for the inclusion body pathology associated with sporadic Parkinson's disease reconsidered. Mov Disord. 2006;21:2042-51.

5. Braak H, Del Tredici K, Rub U, de Vos RA, Jansen Steur EN, Braak E. Staging of brain pathology related to sporadic Parkinson's disease. Neurobiol Aging. 2003:24:197-211.

6. Chaudhuri KR, Buxton-Thomas M, Dhawan V, Peng R, Meilak C, Brooks DJ. Long duration asymmetrical postural tremor is likely to predict development of Parkinson's disease and not essential tremor: clinical follow up study of 13 cases. J Neurol Neurosurg Psychiatry. 2005;76:115-7.

7. Chen-Plotkin AS, Yuan W, Anderson C, McCarty Wood E, Hurtig HI, Clark CM, Miller BL, Lee VM, Trojanowski JQ, Grossman M, Van Deerlin VM. Corticobasal syndrome and primary progressive aphasia as manifestations of LRRK2 gene mutations. Neurology. 2008;70:521-7.

8. Chen S, Le W. Neuroprotective therapy in Parkinson disease. Am J Ther. 2006;13:445-57.

9. Clarimon J, Pagonabarraga J, Paisan-Ruiz C, Campolongo A, Pascual-Sedano B, Marti-Masso JF, Singleton AB, Kulisevsky J. Tremor dominant Parkinsonism: clinical description and LRRK2 mutation screening. Mov Disord. 2008;23:518-23.

10. Deuschl G. Benign tremulous Parkinson's disease: a misnomer? Mov Disord. 2013;28(2):117-9.

11. Deuschl G, Bain P, Brin M. Consensus statement of the Movement Disorder Society on Tremor. Ad Hoc Scientific Committee. Mov Disord. 1998;13 Suppl 3:2-23.

12. Elbaz A, Grigoletto F, Baldereschi M, Breteler MM, Manubens-Bertran JM, Lopez-Pousa S, Dartigues JF, Alperovitch A, Tzourio C, Rocca WA. Familial aggregation of Parkinson's disease: a population-based case-control study in Europe. EUROPARKINSON study group. Neurology. 1999;52:1876-82.

13. Escamilla-Sevilla F, Minguez-Castellanos A. Deep-brain stimulation for Parkinson's disease. N Engl J Med. 2010;363:987. author reply 988.

14. Follett KA, Weaver FM, Stern M, Hur K, Harris CL, Luo P, Marks WJ Jr., Rothlind J, Sagher O, Moy C, Pahwa R, Burchiel K, Hogarth P, Lai EC, Duda JE, Holloway K, Samii A, Horn S, Bronstein JM, Stoner G, Starr PA, Simpson R, Baltuch G, De Salles A, Huang GD, Reda DJ. Pallidal versus subthalamic deep-brain stimulation for Parkinson's disease. N Engl J Med. 2010;362: 2077-91.

15. Geraghty JJ, Jankovic J, Zetusky WJ. Association between essential tremor and Parkinson's disease. Ann Neurol. 1985;17:329-33.

16. Healy DG, Falchi M, O'Sullivan SS, Bonifati V, Durr A, Bressman S, Brice A Aasly J, Zabetian CP, Goldwurm S, Ferreira JJ, Tolosa E, Kay DM, Klein C, Williams DR, Marras C, Lang AE, Wszolek ZK, Berciano J, Schapira AH, Lynch T, Bhatia KP, Gasser T, Lees AJ, Wood NW. Phenotype, genotype, and worldwide genetic penetrance of LRRK2-associated Parkinson's disease: a case-control study. Lancet Neurol. 2008;7:583-90.

17. Hu W, Klassen BT, Stead M. Surgery for movement disorders. J Neurosurg Sci. 2011;55:305-17.

18. Jankovic J, McDermott M, Carter J, Gauthier S, Goetz C, Golbe L, Huber S, Koller W, Olanow C, Shoulson I, et al. Variable expression of Parkinson's disease: a base-line analysis of the DATATOP cohort. The Parkinson study group. Neurology. 1990;40:1529-34.

19. Jankovic J, Tolosa E. Parkinson's disease and movement disorders Urban \& Schwarzenberg. 1998

20. Jellinger K, Paulus W. Clinico-pathological correlations in Parkinson's disease Clin Neurol Neurosurg. 1992;94(Suppl):S86-8.

21. Josephs KA, Matsumoto JY, Ahlskog JE. Benign tremulous Parkinsonism. Arch Neurol. 2006:63:354-7.

22. Koller WC, Rubino FA. Combined resting-postural tremors. Arch Neurol. 1985:42:683-4.

23. Krack P, Batir A, Van Blercom N, Chabardes S, Fraix V, Ardouin C, Koudsie A, Limousin PD, Benazzouz A, LeBas JF, Benabid AL, Pollak P. Five-year followup of bilateral stimulation of the subthalamic nucleus in advanced Parkinson's disease. N Engl J Med. 2003;349:1925-34.

24. Lance JW, Schwab RS, Peterson EA. Action tremor and the cogwheel phenomenon in Parkinson's disease. Brain. 1963:86:95-110.

25. Lee MS, Kim YD, Im JH, Kim HJ, Rinne JO, Bhatia KP. 123I-IPT brain SPECT study in essential tremor and Parkinson's disease. Neurology. 1999;52:1422-6.

26. Leventoglu A, Baysal Al. Benign tremulous Parkinson's disease. Acta Neurol Belg. 2008;108:48-52.

27. Limousin P, Speelman JD, Gielen F, Janssens M. Multicentre European study of thalamic stimulation in Parkinsonian and essential tremor. J Neurol Neurosurg Psychiatry. 1999;66:289-96.

28. Ling $\mathrm{H}$, Lees AJ. How can neuroimaging help in the diagnosis of movement disorders? Neuroimaging Clin N Am. 2010;20:111-23.

29. Louis ED, Jurewicz EC. Olfaction in essential tremor patients with and without isolated rest tremor. Mov Disord. 2003;18:1387-9.

30. McKeith IG, Dickson DW, Lowe J, Emre M, O'Brien JT, Feldman H, Cummings, J, Duda JE, Lippa C, Perry EK, Aarsland D, Arai H, Ballard CG, Boeve B, Burn DJ, Costa D, Del Ser T, Dubois B, Galasko D, Gauthier S, Goetz CG, Gomez-Tortosa E, Halliday G, Hansen LA, Hardy J, Iwatsubo T, Kalaria RN, Kaufer D, Kenny RA, Korczyn A, Kosaka K, Lee VM, Lees A, Litvan I, Londos E, Lopez OL, Minoshima S, Mizuno Y, Molina JA, Mukaetova-Ladinska EB, Pasquier F, Perry RH, Schulz JB, Trojanowski JQ, Yamada M. Diagnosis and management of dementia with Lewy bodies: third report of the DLB Consortium. Neurology. 2005;65:1863-72.

31. Muller T. Drug therapy in patients with Parkinson's disease. Trans Neurodegener. 2012;1:10

32. Nussbaum RL, Ellis CE. Alzheimer's disease and Parkinson's disease. N Engl J Med. 2003;348:1356-64.

33. Okun MS. Deep-brain stimulation for Parkinson's disease. N Engl J Med. 2012;367:1529-38.

34. Payami H, Larsen K, Bernard S, Nutt J. Increased risk of Parkinson's disease in parents and siblings of patients. Ann Neurol. 1994;36:659-61.

35. Poewe WH, Wenning GK. The natural history of Parkinson's disease. Neurology. 1996;47:S146-152.

36. Quinn NP, Schneider SA, Schwingenschuh P, Bhatia KP. Tremor-some controversial aspects. Mov Disord. 2011;26:18-23. 
37. Rizzo G, Marconi S, Capellari S, Scaglione C, Martinelli P. Benign tremulous Parkinsonism in a patient with dardarin mutation. Mov Disord. 2009;24: 1399-401.

38. Rocca WA, McDonnell SK, Strain KJ, Bower JH, Ahlskog JE, Elbaz A, Schaid DJ, Maraganore DM. Familial aggregation of Parkinson's disease: the Mayo clinic family study. Ann Neurol. 2004;56:495-502.

39. Russell DS. Benign tremulous Parkinsonism. Arch Neurol. 2006;63:1346.

40. Savica R, Matsumoto JY, Josephs KA, Ahlskog JE, Stead M, Lee KH, Klassen BT. Deep brain stimulation in benign tremulous Parkinsonism. Arch Neurol. 2011;68:1033-6.

41. Selikhova M, Kempster P.A, Revesz T, Holton J.L, Lees A.J. Neuropathological findings in benign tremulous Parkinsonism. Mov Disord. 2012;28(2):145-152.

42. Van Horn G, Schiess MC. Benign tremulous Parkinsonism? Arch Neurol. 2006;63:1507.

Submit your next manuscript to BioMed Central and we will help you at every step:

- We accept pre-submission inquiries

- Our selector tool helps you to find the most relevant journal

- We provide round the clock customer support

- Convenient online submission

- Thorough peer review

- Inclusion in PubMed and all major indexing services

- Maximum visibility for your research

Submit your manuscript at www.biomedcentral.com/submit
Biomed Central 